\title{
Does a four-week intensive scoliosis-specific exercise programme improve quality of life and decrease patient-reported pain in subjects with idiopathic scoliosis and is this improvement maintained at short-term follow-up?
}

\author{
Erika Maude*, Laura Harman, Timothy Rolfe \\ From 7th International Conference on Conservative Management of Spinal Deformities \\ Montreal, Canada. 20-22 May 2010
}

\section{Introduction (research question)}

The studies in this presentation investigate whether a four-week intensive scoliosis-specific exercise programme results in an improvement in patient reported pain and an increase in quality of life for subjects with idiopathic scoliosis and if so, are these improvements maintained at short-term follow-up?

\section{Material and methods}

These studies used a quantitative and qualitative methodology; all patients had idiopathic scoliosis and were treated with a four-week intensive course of scoliosisspecific physiotherapy (the ScolioGold method). A sample of 35 patients (mean age 28.89 years) and 96 patients (mean age 30.51 years) were included in the pain and quality of life studies, respectively. Patients were asked to rate their level of pain and quality of life on the first day of treatment, at the end of the four-week course and at their subsequent check-up appointments. Patient-reported pain was assessed using a ten point, vertical, visual analogue scale and patient-reported quality of life was assessed using a modified version (replacing 'surgery' with 'treatment') of the SRS-30 questionnaire.

\section{Results}

The mean pain score before treatment was 4.77 , at the end of the four-week course it had reduced to 2.49 and at 6 months follow-up it was 2.06. The mean total SRS30 score before treatment was 3.44 , at the end of the four-week course it had increased to 3.75, at 6 months follow-up it was 3.81 and after 12 months it was 3.73 .

\section{Discussion}

There was a statistically significant reduction (Friedman's ANOVA $\mathrm{p}=<0.001$ ) in patient-reported pain between pre and post treatment. At 6 month's follow-up this reduction had been maintained and patient-reported pain levels actually continued to decrease. Improvements in quality of life between pre and post treatment were also found to be statistically significant (paired $\mathrm{t}$-test $\mathrm{p}=<0.001$ ). This was reflected in all subscales, with the exception of function. This improvement is maintained with no statistically significant deterioration in a period of up to 12 months after the initial four week treatment course. Again, this was reflected in all subscales, including function.

\section{Conclusion}

Short-term results substantiate the use of intensive exercise methods, such as ScolioGold, in the treatment of patients with idiopathic scoliosis who suffer pain and/or those who have a reduced quality of life and add to the growing body of evidence for scoliosis-specific physiotherapy. However, future research is required to establish the effects of intensive exercise

Scoliosis SOS Clinic, Martlesham, Suffolk, England

Full list of author information is available at the end of the article 
on scoliosis-related pain and patient's quality of life in the mid- to long term.

Published: 10 September 2010

doi:10.1186/1748-7161-5-S1-026

Cite this article as: Maude et al:: Does a four-week intensive scoliosisspecific exercise programme improve quality of life and decrease patient-reported pain in subjects with idiopathic scoliosis and is this improvement maintained at short-term follow-up? Scoliosis 20105

(Suppl 1):026.

Submit your next manuscript to BioMed Central and take full advantage of:

- Convenient online submission

- Thorough peer review

- No space constraints or color figure charges

- Immediate publication on acceptance

- Inclusion in PubMed, CAS, Scopus and Google Scholar

- Research which is freely available for redistribution

Submit your manuscript at www.biomedcentral.com/submit 